\title{
OFFSET IMPLEMENTATION IMPACT ON TECHNOLOGY TRANSFER IN BULGARIA
}

\author{
Venelin Terziev $^{1 *}$, Veselin Madanski ${ }^{2}$, Marin Georgiev ${ }^{3}$ \\ ${ }^{1}$ Corresponding Member of the Russian Academy of Natural History, Moscow, Russia, Professor, \\ Ph.D., D.Sc. (National Security), D.Sc. (Ec.), University of Rousse, Rousse, Bulgaria; National \\ Military University, Veliko Tarnovo, Bulgaria; University of Telecommunications and Post, Sofia, \\ Bulgaria, terziev@skmat.com \\ ${ }^{2}$ Colonel Associate Professor, Ph.D., D.Sc. (National Security), National Military University, Veliko \\ Tarnovo, Bulgaria, madansky@yahoo.com \\ ${ }^{3}$ National Military University, Veliko Tarnovo, Bulgaria, clementon@abv.bg \\ ${ }^{*}$ Corresponding author
}

\begin{abstract}
The Republic of Bulgaria is striving to create conditions for ensuring of the whole life cycle of the obtained products while applying the offset politic and programs. Simultaneously with it, the compensation mechanisms are aimed at achieving additional economic, technological and financial benefits for the industry and for the whole country. With its offset policy, the Republic of Bulgaria strives to contract the investments and the transfer of know-how and technologies for the companies of its defence industry. The effective implementation of the offset policy makes a perfect opportunity not only for the investments and the transfer of technologies, but also for the acquisition of the best weapon at a good price and for the insurance of the life cycle of the military products.
\end{abstract}

Keywords: offset, army, technology, defence.

\section{INTRODUCTION}

While applying the offset politic and programs, the Republic of Bulgaria is striving to create conditions for ensuring of the whole life cycle of the obtained products. Simultaneously with it, the compensation mechanisms are aimed at achieving additional economic, technological and financial benefits for the industry and for the whole country. The implementation of offset programs from potential strategic partners creates conditions for participation of the companies form the Bulgarian industry into projects for modernization of the armed forces and for the increasing of the resources of the national production and technological basis. The refore the requirements to the possible foreign partners include the participation of Bulgarian companies and the achievement of a definitely highly technological nature of the proposed offset agreements (Susanyan, 2013, pp. 63-70; Terziev, Nichev, 2016e, pp. 135-140). The significant defensive technologies are being controlled by different prohibition regulations and can't be purchased. The experience shows, that it's not the business organizations, but the governments, who reject the transfer of technologies, what makes them 
unobtainable [3-4] (Nichev, N. 2017a; Nichev, N. 2017b). In such situations the offset programs afford the suitable opportunity for acquiring of technologies.

In their research Radhakrishnan, Prahlada and Kumar emphasize the importance of the offset programs for acquiring of defensive technologies (Radhakrishnan, Kumar, 2009, pp. 114-125). They consider, that the technologies are not just a product, but a combination between science and engineering. The developed technologic countries are aware how powerful technologies are and try to control their spreading by means of controlled regimes. Technologies are important, because the acquiring of critical technologies have the following advantages: they permit the design, development and production of technological systems; a big share of direct and indirect applications of a number of technologies can be inherited; they enable the development of new technologies; the allow the industry to manufacture products and to handle them; they contribute to the development of defensive industrial basis of the countries, which possess the relevant defensive technologies.

\section{THE ROLE OF OFFSET IN TECHNOLOGY TRANSFER}

In order to increase the utilization of the offset for the acquiring of technologies, it's necessary to know what critical and specialized equipment will be needed. Based on the strategy for the development of the Bulgarian defensive-technological industrial basis, Terziev and Nichev determine the following priority product groups: ammunitions and small arms, steerable and non-steerable missiles; repair and modernization of military equipment for different kinds of armed forces (mainly of Russian/ Soviet Union origin); equipment for radio-electronic defence, detection, counteraction and protection from improvised explosive devices; equipment for identification and radar awareness; equipment for passive and active defence of the human resources and military equipment; unmanned aerial vehicles; definite kinds of precise and steered ammunitions; communication and information systems; systems for monitoring and protecting of parts of the maritime and land borders of the Republic of Bulgaria (Terziev, Nichev, 2016d; Terziev, Nichev, 2016e).

Analysing the technological transfer by means of performing of offset transactions, Ravindran stresses on the importance of the offset for the acquiring of defensive resources by the countries and indicates the ways of implementation of such a transfer (Ravindran, 2009, pp. 135-148). Some of the most important accessible ways of technological transfer using offset transaction for the recipient countries are the following:

- Collaborative production. It is considered to be a very effective mechanism for the transfer of modern technologies and their utilizing. In the modern programs for development of collaborative productions, the access to technologies for the partnering parties is implemented using significantly less time and financial resources. By means of this process the participating parties become partners at fixed levels, depending on the made contributions. It's advisable to include the joint intellectual property rights and the shared positions at the international markets as an integral part of the concluded offset agreement, ensuring this way a fair distribution of the earned revenues for the participating Bulgarian companies. The transfer of technologies can be implemented by means of establishing of joint ventures, whereby in this case the amount of the investments is of great importance. Ravindran describes cases, where joint ventures have become inoperable for reasons of morally outdated equipment.

- Subcontractor. The obligations of a contractor are being implemented, when a foreign company places an order, connected with defines components, subsystems or products, for export by the industry in the countries, where the seller must fulfil the offset obligations. For a short period, the agreement for production as a subcontractor party represents an effective way for the Bulgarian production to approach the modern high-tech manufacturing. The awarding of the activity to the subcontractor can be implemented by means of giving him the full documentation package for the production or by means of providing detailed technical documentation.

- Manufacturing under license. From the point of view of the seller, he assigns his competitive advantage when transferring the whole technology regarding the product. For this reason the size of the granted technology and ownership elements is selected by the seller. This predetermines the fact, that the buyer is not in position to take maximum advantage of the transfer of technologies and there always exists a divergence between the expectations of the buyer and the offer of the seller.

- Maintenance and training. The long-term activities for training of the local industrial partners by means of applicable levels of technological transfer represent an obligatory element of the modern market economy. By creating facilities for training of the human resources, such as: flight simulators, training centres, centres for experience studies and others, this requirement is being adequately fulfilled. From the point of view of 
technologies transfer by means of offset transactions, it's an effective way of acquiring competences and abilities by the buyer state.

Samaddar defines the technological transfer as the most popular and preferred kind of offset in the world, particularly for the countries, which are striving to build their own industrial base. He determines that the technological transfer occupies more than $30 \%$ of all kinds of offset (Samaddar, 2009, pp. 81-104).

The success of the technological transfer requires well defined bases. Firstly, the technological transfer needs to be economically stabile. Secondly, the recipient industry must possess the technological capacity and based on it to permit the mastering of the relevant technology. Third, Samaddar points that the technological transfer mustn't be limited by restrictive conditions. The insertion of restrictive conditions may result in disagreements during the drawing up of an Offset contract. Fourth, it's advisable for the local defence industry to ask for transfer of technologies only in case, when such transfer can be self-sufficient through added value of the innovations, in order to develop the next generation of defence product. Fifth, it's necessary that the buyer state is sure to acquire the newest and the most updated technologies. The widespread opinion of the researchers is that the newest technological decisions are shall not offered by the transfer of technologies, in order for the owner of the relevant technology not to lose his competitive advantage. This is proved also by the legally imposed regulations for control of the export by the countriessuppliers on the eventual buyers. Sixth, it's necessary to evaluate the real influence and effectiveness of the technological transfer. Samaddar considers that the mathematical models, the theory of usefulness and the theory of the rational choice can be used by the evaluation of the expenses and the benefits of the technological transfer.

According to Terziev and Nichev, the problems and the challenges facing the transfer of technologies are: the importance of the technological transfer, the international market, the expected returns, the license agreements, the weight ratios and the technology of evaluation (Nichev, Terziev, 2016, pp. 141-146; Terziev, Nichev, 2016a, pp. 101-106; Terziev, Nichev, 2016b, pp. 385-391; Terziev, Nichev, 2016e, pp. 135-140).

Importance of the technological transfer: the seller can offer a transfer of technologies, which are not directly connected with the product or with the manufacturing process, they are delivered from. Hence, the offers from foreign suppliers need a careful and profound analysis, in order to guarantee, that the offered technology is important for the current and future application in the defence-industrial technological basis. The practice for retention of the ownership over critical (key) technologies by the sellers imposes to pay special attention on those technologies during the negotiations regarding the contract.

International market - the technology, which is at hand to be acquired, must be conformed to the possessed positions on the international market and to the opportunities for preserving of these positions and for the acquisition of new market shares. This will facilitate the avoiding of acquisition of technologies, which are close to the end of their life cycle or are already out of use (Terziev, Nichev, 2016c, pp. 366-373).

Expected redeemability - besides the most important aspect - ensuring of the national security of the buyer, for which reason happens the acquiring of the necessary technologies, it's important that the offered technology results in redeem- ability of the invested financial resources. This can be achieved through implementation of the defence product on the internal market, on the international market, or on both markets and this necessitates this market potential and the returns, connected with it, to be evaluated.

License agreements: Often the technology, which is desired to be acquired, is a subject of approval by a foreign government and in this way the acquisition of the newest technologies happens exceptionally difficult. Even in the cases, when the supplier is ready to sell the technology and offers a particular price, the relevant governments don't admit them, referring to the regulations for control of the export. Some technologies are banned for export for definite countries or organizations.

Weight ratios: When the transfer of technologies is a key component of the offset agreement, in order to stimulate the foreign suppliers of the necessary technology, the importing countries apply widely the weight ratios. For Bulgaria the valid weight ratio in the offset transactions, where the transfer of technologies is a basic element can reach to 5 in the cases, when the technology is of a special interest for the production of the main defence products and arms systems (Methodology for the evaluation of the criterion "offset program" on public tenders according to clause 6 of the Public Procurement and Concessions Act in the Ministry of Defence, Directorate „Policy for Armament“, Sofia, 2003.

Evaluation technology: the evaluation of the technology is a complicated and difficult process, where subjectivism prevails. This is, actually the biggest challenge in the whole process of transfer of technologies. The evaluation is a critical component and is of considerable importance in the process of transfer of technologies and it ought to be performed in the most precise and transparent way, as far as possible. The 
offset agreements and contracts meet various requirements of the state authorities for concluding of contracts with a foreign supplier. If the government intends to use the offset transaction for direct production compensations and/or for transfer of technologies in the sphere of the acquired defence product, then the offset price is based on the amount of the expenses for the production and/or the price of the technology.

In the case of transfer of technologies, the offset price is based on a full analysis of the price of the technology, regardless of that, whether the technological transfer is implemented independent or is a component of a bigger offset transaction. It's reasonable that the technology evaluation pays takes into consideration the following aspects:

Detailed information concerning the technology itself and its applications: In the modern industrial society the technology, used for the production of a particular defence product, is a prerequisite for the production of other products, thus stimulating the manufacturing and the resulting marketing of these products. Many defence technologies have a possible dual-use and this way facilitate the development of the manufacture of civil production. It's necessary to consider the expenses on a technology for completely new products, taking into account the replacement of the existing products from older projects or technologies, as means of enforcement of the production of new defence products.

Expected effect of the technology concerning the profits: The production of defence products is more difficult using outdated processes, which results into a higher prime cost and lower profit. Hence, the influence of the new technologies in respect of the implemented technological process is fulfilled by means of increase of the activity profit.

Technological influence in respect of the partial improvement obtained from inventions. According to Ravindran, in most of the cases the expenses on products and services, based on the gradual implementation of inventions in the available technologies, are higher than those, spent for revolutionary new technologies. Initially they could be cost more, but the ir redeem ability and the resulting profits are implemented on a later stage of the defence product life.

Potential of the market: The defence products, directly based on foreign technologies, are expected to go beyond the limits of the national market. When the product is being elaborated by the local defencetechnological industrial base using an approved and established on the market technology, it penetrates easily also into the international markets. In the cases of acquisition of technologies with dual-use, the products of civil purpose may have a wider market in the country-buyer. Sometimes the market is not ready for a specific technology and the implementation of the new technology at such market could appear to be economically unreasonable and even to result in total rejection of the product by the market.

Competitive advantages: When a particular national defence-technological industrial base obtains access to the international markets, it derives competitive advantages in relation to other suppliers. It's transformed into definite profits, owed to the lower production costs. The competitive advantage is usually implemented through low operation expenses, production of a new product and providing of products and services, linked to the main product.

Availability of alternative technologies: The problems with the licensing by foreign governments sometimes force the Bulgarian defence-technological industrial base to select alternative technologies, which are easier accessible. In cases of revolutionary new technologies, alternative technologies exist rarely. Another attendant problem of the alternative technologies is the acceptability of such technologies, expressed in possible deviation in the standard of the defence product.

Development stage of the defence product: The defence product can be on some stage of its development, such as: primary researches (proof of the concept), presentation of the product, development, pilot project and production. The common system projects are influenced by the available technologies during the development of the product concept. In the cases, when the implementation of the technological system is already advanced, it's reasonable to evaluate the available technologies and to seek for new ones, in order to implement a part of the system, which can be or can't be implemented on a later stage. The implementation of a new technology for the production of a particular defence product close to the end of its life is economically unreasonable.

\section{CONCLUSION}

In conclusion it's necessary to emphasize that against the background of the running in the EU processes for denial of the offset, in Bulgaria still exists a strong national interest in preserving the offset as a form and instrument for the transfer of technologies. Precisely with its offset policy, the Republic of Bulgaria strives to contract the investments and the transfer of know-how and technologies for the companies of its defence 
industry. The effective implementation of the offset policy makes a perfect opportunity not only for the investments and the transfer of technologies, but also for the acquisition of the best weapon at a good price and for the insurance of the life cycle of the military products.

\section{REFERENCES LIST}

Susanyan, K. (2013). „Role of the offset transactions in the international and Russian foreign trade”. Russian Gazette for Foreign Economy, Moscow, Issue 2.

Nichev, N. (2017a). Offset Policies of the Countries of the European Union. New knowledge Journal of science, Vol 6, No 1.

Nichev, N. (2017b). Perspectives for Use of the Offset Deals. New knowledge Journal of scence, Vol 6, No 1.

Nichev, N., Terziev, V. (2016). Osobenosti na ofseta kato sredstvo za pridobivane na vaorazhenie i tehnika za nuzhdite na vaorazhenite sili na Republika Bulgaria. Nauchni trudove na Sayuza na uchenite v Bulgaria- Smolyan, Tom 2.

Ravindran, S. (2009). Technology Inflows: Issues, Challenges and Methodology. Journal of Defence Studies, Vol.3, No.1, retrived from: http://www.idsa.in/jds/3_1_2009_OffsetAbsorption_SSamaddar.

Radhakrishnan S., Pr., Kumar., P. (2009). Leveraging Defence Offset Policy for Technology Acquisition. Journal of Defence Studies, Vol. 3, No. 1.

Samaddar, S. (2009). Offset Absorption: Adding Arsenal to Armament. Journal of Defence Studies, Vol. 3, No. 1, 2009, retrived from: http://www.idsa.in/jds/3_1_2009_OffsetAbsorption_SSamaddar.

Terziev, V., Nichev N. (2016). Economic characteristics of offset transactions with defense products. Scientific journal „Economics and finance“ EDEX, Madrid, España.

Terziev, V., Nichev, N. (2016). Tendentsii v razvitieto na svetovnia pazar na otbranitelni produkti. Yuridicheski sbornik, tom XXIII, Burgaski svoboden universitet, Tsentar po yuridicheski nauki, Burgas.

Terziev, V., Nichev, N. (2016). Sravnitelen analiz na prilaganeto na ofseta pri sdelki s otbranitelni produkti. Yuridicheski sbornik, tom XXIII, Burgaski svoboden universitet, Tsentar po yuridicheski nauki, Burgas.

Terziev, V., Nichev, N. (2016). Ofseta kato spetsifichen vid ikonomicheska deynost. Mezhdunarodna nauchna konferentsia Uniteh'16, Sbornik dokladi, Tom IV, Tehnicheski universitet - Gabrovo.

Terziev, V., Nichev, N. (2016). Rolyata na ofsetnite sdelki za pridobivane na novi tehnologii. Mezhdunarodna nauchna konferentsia Uniteh'16, Sbornik dokladi, Tom IV, Tehnicheski universitet - Gabrovo.

Decree Nr.180 of 22 August 2013 for adopting of Regulation according to clause 6 of the Public Procurement and Concessions Act for the criteria and the system for determination of the major national interests in the sphere of protection and defence in the sense of clause 346 of the Agreement for the functioning of the European Union and according to the order of contracting. State Gazette, issue 75 of 27.8.2013.

Methodology for the evaluation of the criterion "offset program" on public tenders according to clause 6 of the Public Procurement and Concessions Act in the Ministry of Defence, Directorate „Policy for Armament“, Sofia, 2003. 